\title{
Correction to: Inhibition of PAD4 enhances radiosensitivity and inhibits aggressive phenotypes of nasopharyngeal carcinoma cells
}

Hao Chen ${ }^{1 \dagger}$, Min Luo $^{1+}$, Xiangping Wang ${ }^{1}$, Ting Liang ${ }^{1}$, Chaoyuan Huang ${ }^{1}$, Changjie Huang ${ }^{1 *}$ and Lining Wei ${ }^{2^{*}}$

The original article can be found online at https://doi.org/ 10.1186/s11658-021-00251-2.

*Correspondence: hcj1215423068@hotmail.com; weilininggudy@163.com ${ }^{\dagger} \mathrm{Hao}$ Chen and Min Luo contributed equally to this work ${ }^{1}$ Department of Oncology, The Second Nanning People's Hospital, No. 13 Dancun Road, Jiangnan District, Nanning 530031, Guangxi, China

2 Department of Endoscopy, The Affiliated Tumor Hospital of Guangxi Medical University, Nanning 530021, Guangxi, China

\section{Correction to: Cell Mol Biol Lett (2021) 26:9}

https://doi.org/10.1186/s11658-021-00251-2

Following publication of the original article [1], we have been informed that the authors Hao Chen and Lining Wei were incorrectly affiliated.

The author group has been updated above and the original article [1] has been corrected.

Published online: 30 December 2021

Reference

1. Chen H, Luo M, Wang X, Liang T, Huang C, Huang C, Wei L. Inhibition of PAD4 enhances radiosensitivity and inhibits aggressive phenotypes of nasopharyngeal carcinoma cells. Cell Mol Biol Lett. 2021;26:9. https://doi.org/10.1186/ s11658-021-00251-2.

\section{Publisher's Note}

Springer Nature remains neutral with regard to jurisdictional claims in published maps and institutional affiliations.

(c) The Author(s) 2021. Open Access This article is licensed under a Creative Commons Attribution 4.0 International License, which permits use, sharing, adaptation, distribution and reproduction in any medium or format, as long as you give appropriate credit to the original author(s) and the source, provide a link to the Creative Commons licence, and indicate if changes were made. The images or other third party material in this article are included in the article's Creative Commons licence, unless indicated otherwise in a credit line to the material. If material is not included in the article's Creative Commons licence and your intended use is not permitted by statutory regulation or exceeds the permitted use, you will need to obtain permission directly from the copyright holder. To view a copy of this licence, visit http:// creativecommons.org/licenses/by/4.0/. 